\title{
Tannin Assays in Ecological Studies: Lack of Correlation Between Phenolics, Proanthocyanidins and Protein-Precipitating Constituents in Mature Foliage of Six Oak Species
}

\author{
Joan Stadler Martin and Michael M. Martin \\ Division of Biological Sciences, University of Michigan, Ann Arbor, MI 48109, USA
}

\begin{abstract}
Summary. There is no correlation between protein-precipitating capacity and either total phenolic or proanthocyanidin content of extracts of mature foliage from six species of oaks: Quercus alba (white oak), Q. bicolor (swamp white oak), Q. macrocarpa (bur oak), Q. palustris (pin oak), $Q$. rubra (red oak), and $Q$. velutina (black oak). It is argued that studies which probe the role of tannins in the selection and utilization of food by herbivores should include a protein-precipitation assay, since such an assay provides a measure of the property of tannins which is presumed to contribute to their utility as defensive compounds. A convenient modification of the bovine serum albumin (BSA) precipitation assay, which measures the amount of protein precipitated when a plant extract is added to a BSA solution, is described. Advantages of this procedure recommend its routine adoption in studies of the role of tannins in plant-herbivore interactions.
\end{abstract}

\section{Introduction}

Tannins are naturally occurring, water-soluble phenolic compounds in the 500 to 3,000 molecular weight range, having the property of precipitating proteins from aqueous media (Ribéreau-Gayon 1972; Haslam 1979; Swain 1979 a, b). They have been accorded an important role in protecting plant tissues from herbivore attack (Feeny 1976; Rhoades and Cates 1976). Commencing with Feeny's classic investigation of the inhibiting effects of oak leaf tannins on larval growth by the winter moth, Operophthera brumata (Feeny 1968, 1970), a series of papers (Fox and Macauley 1977; Chan et al. 1978; McKey et al. 1978; Rhoades 1979; Bernays et al. 1980, 1981; Moran and Hamilton 1980; Oates et al. 1980; Waterman et al. 1980; Lawson et al. 1982) has appeared shaping contemporary views concerning the significance of these substances in plant-herbivore interactions. Since tannins constitute a structurally heterogeneous class of compounds, they do not lend themselves to easy quantification, and investigations of the importance of tannins in food selection and utilization have been hampered by deficiencies in the methods used to assay for tannin content.

The procedures most frequently used in ecologically oriented studies have been the Folin-Denis assay (Swain and Hillis 1959), the proanthocyanidin assay (Hillis and Swain 1959; Govindarajan and Mathew 1965) and the vanillin/HCl assay (Burns 1971; Price et al. 1978). The appeal of these three methods is the ease with which they can be performed, but each has serious shortcomings as an assay for tannin content (Swain 1979a). In all three the extent of color development depends upon the molecular structures as well as the amounts of the tannins present. In addition, non-tannic constituents can contribute to color development. Furthermore, the proanthocyanidin and vanillin/ $\mathrm{HCl}$ assays depend upon structural elements present only in the condensed tannins, and hence provide no measure of hydrolyzable tannins.

Since tannins form insoluble complexes with proteins (van Sumere et al. 1975), another approach to measuring the amount of tannin in an extract has been to determine its capacity to precipitate proteins from solution. Assays involving the precipitation of $\beta$-glucosidase (Goldstein and Swain 1965), hemoglobin (Bate-Smith 1973; Schultz et al. 1981), and bovine serum albumin (Hagerman and Butler 1978) have been described. Since it is the capacity of tannins to precipitate proteins, especially digestive enzymes or ingested food plant proteins, which is postulated to be responsible for the adverse effects which these substances have on many organisms, these assays would appear to be particularly appropriate ones in studies of the significance of tannins in herbivory. To date, however, such procedures have found only limited use by investigators of plant-herbivore interactions.

In this study we have performed Folin-Denis, proanthocyanidin, and two different protein-precipitation assays on extracts of the mature foliage of six species of oaks: white oak (Quercus alba), swamp white oak ( $Q$. bicolor), bur oak (Q. macrocarpa), pin oak (Q. palustris), red oak (Q. rubra), and black oak $(Q$. velutina). While the results of the two protein-precipitation assays are highly correlated, the protein-precipitation assays, the Folin-Denis assay, and proanthocyanidin assay provide three entirely different pictures of the chemical defenses of these species. Bate-Smith (1977) and Swain (1979 b) have pointed out the problems inherent in using chemical, functional group assays to evaluate tannin content. Our comparison of the foliage of six oak species underscores the cogency of their remarks, and argues strongly for the use of a protein-precipitation assay in studies designed to probe the significance of tannins in plantherbivore interactions. 


\section{Materials and Methods}

\section{Preparation of Extracts}

Mature foliage (Lawson et al. 1982), frozen immediately after collection and subsequently lyophilized, was ground in a Wiley mill (40-mesh) after removal of the midrib. Ground leaf powder was stored in a desiccator until analysis. Leaf powder $(60.0 \mathrm{mg})$ was extracted twice for $8 \mathrm{~min}$ utes with $4 \mathrm{ml}$ of boiling $50 \%(\mathrm{v} / \mathrm{v})$ aqueous methanol in a centrifuge tube (capped with a marble) placed in a heat block at $95^{\circ} \mathrm{C}$. After centrifugation $(12,000 \times g, 15 \mathrm{~min}$, $5^{\circ} \mathrm{C}$ ), the pellet was resuspended in a small volume of $50 \%$ methanol and centrifuged as before. The volume of the combined supernatants was adjusted to $10 \mathrm{ml}$, and dilutions appropriate to each assay were prepared from aliquots of this stock solution.

\section{Assays}

Folin-Denis Assay (Swain and Hillis 1959; Ribéreau-Gayon 1972). Aliquots of the stock extract derived from $0.06,0.12$, 0.18 , and $0.24 \mathrm{mg}$ (dry weight) of leaf powder were diluted to $2.8 \mathrm{ml}$ by the addition of water, and $0.2 \mathrm{ml}$ of the FolinDenis reagent was added with vigorous vortexing. Three minutes later, $0.4 \mathrm{ml}$ of a saturated solution of sodium carbonate and $0.6 \mathrm{ml}$ of water were added. After $60 \mathrm{~min}$ at room temperature, absorbance at $725 \mathrm{~nm}\left(\mathrm{~A}_{725}\right)$ was measured, zeroing the spectrophotometer with a tube containing all of the reagents plus water in place of the extract. A calibration curve was constructed from commercial tannic acid, TA (Sigma Lot 73C-1480), found to contain $6.4 \%$ moisture: $\mathrm{A}_{725}=0.0199$ ( $\mu \mathrm{g} \mathrm{TA}$ in assay mixture) -0.0034 , in the range 5-25 $\mu \mathrm{g} \mathrm{TA}(r=0.998$, standard error of regression coefficient $=0.0004$ ). This regression was used to calculate the tannic acid equivalents ( $\mu \mathrm{g}$ TAE) present in the extracts.

Proanthocyanidin Assay (Hillis and Swain 1959; Govindarajan and Mathew 1965). Aliquots of extract derived from $0.6,0.9,1.2,1.5$ and $1.8 \mathrm{mg}$ leaf powder, diluted to $0.3 \mathrm{ml}$, were vortexed with $3.0 \mathrm{ml}$ of a solution of $80 \%$ butanol$\mathrm{HCl}$ (preheated to $97^{\circ} \mathrm{C}$ ) containing $15.4 \%$ (w/v) ferrous sulfate. Heating at this temperature was continued for $15 \mathrm{~min}$, during which time the assay tube was capped by a marble to allow refluxing of solvent. Absorbance at $550 \mathrm{~nm}\left(\mathrm{~A}_{550}\right)$ was compared immediately to an unheated control, zeroing against distilled water. A calibration curve was constructed using commercial bisulfited quebracho, $\mathrm{BQ}$ (Pilar River Plate Corp., Newark, New Jersey) found to contain $18 \%$ moisture: $\Delta \mathrm{A}_{550}=0.0020(\mu \mathrm{g} \mathrm{BQ}$ in the assay mixture $)+0.0418$, in the range $25-250 \mu \mathrm{g} \mathrm{BQ}(r=0.997$, standard error of regression coefficient $=0.00009$ ). This regression was used to calculate the bisulfited quebracho equivalents ( $\mu \mathrm{g} \mathrm{BQE})$ present in the extracts.

B-Glucosidase Precipitation Assay (Goldstein and Swain 1965). The aqueous methanolic solvent from $5.0 \mathrm{ml}$ of the stock extract was removed at room temperature and reduced pressure using a rotary concentrator, and the residue was redissolved in $3.75 \mathrm{ml}$ of acetate buffer $(0.1 \mathrm{M}, \mathrm{pH} 4.8)$ by rotary agitation for $30 \mathrm{~min}$. Aliquots of this solution, containing dissolved extractives from 0.24 to $1.68 \mathrm{mg}$ of leaf powder, diluted to $0.3 \mathrm{ml}$ with acetate buffer $(0.1 \mathrm{M}$, $\mathrm{pH} 4.8$ ), were vortexed with $0.3 \mathrm{ml}$ of a solution of $\beta$-gluco- sidase (Sigma G-8625, Lot 40 F-4017) $(0.5 \mathrm{mg} / \mathrm{ml})$ in phosphate buffer $(0.1 \mathrm{M}, \mathrm{pH} 7.0)$, and then allowed to stand at room temperature for $15 \mathrm{~min}$. After centrifugation $\left(12,000 \times \mathrm{g}, 15 \mathrm{~min}, 5^{\circ} \mathrm{C}\right)$, the activity of the enzyme in the supernatant was determined in triplicate by combining a $50 \mu \mathrm{l}$ aliquot with $3.0 \mathrm{ml}$ of acetate buffer $(0.1 \mathrm{M}, \mathrm{pH} 4.8)$ containing esculin $(0.5 \mathrm{mM})$ and aluminum chloride $\left(3.75 \mathrm{mM}\right.$ ) at $25^{\circ} \mathrm{C}$, and following the change in absorbance at $385 \mathrm{~nm}\left(\Delta \mathrm{A}_{385}\right)$ for $3.5 \mathrm{~min}$ on a self-zeroing Zeiss PMQ-II spectrophotometer zeroed against water. The change in $\mathrm{A}_{385}$ was demonstrated to be linear for at least 9 minutes. From a determination of the activity in the original enzyme solution $(1.2-1.6$ units $/ \mathrm{ml})$, the number of units of activity precipitated by the addition of the extract was calculated. One unit is the amount of enzyme which liberates 1 micromole of product per minute under the conditions of the assay. Assuming that the esculetin-aluminum chloride complex generated in this procedure has the same extinction coefficient as the one generated in the original procedure of Goldstein and Swain (1965), a $\Delta \mathrm{A}_{385}$ of $1 \mathrm{~A}$ unit/minute corresponds to 0.45 units of enzyme activity. A plot of units of activity precipitated vs. $\mathrm{mg}$ leaf powder suggests a possible sigmoidal dependence, but the middle portion of the curve closely approximates linearity. Linear regressions were fitted to the nearly linear regions of these curves.

BSA Precipitation Assay: Determination of Protein Precipitated. Aliquots of the stock extract derived from 1.38, 2.07, $2.76,3.45$, or $4.14 \mathrm{mg}$ of leaf powder, diluted to $0.69 \mathrm{ml}$ with $50 \%$ aqueous methanol, were vortexed with $1.39 \mathrm{ml}$ of a solution $(1 \mathrm{mg} / \mathrm{ml})$ of crystallized, lyophilized BSA (Sigma, Lot 70F-9350) in acetate buffer (0.2 M, pH 5.0) containing $0.17 \mathrm{M}$ sodium chloride, and allowed to stand at room temperature for 15 minutes. After centrifugation $\left(12,000 \times g, 15 \mathrm{~min}, 5^{\circ} \mathrm{C}\right)$, the pellet was rinsed gently with $0.42 \mathrm{ml}$ of the same buffer, centrifuged as before, and the supernatants combined to give a final volume of $2.5 \mathrm{ml}$, which was applied to a $1.7 \times 5.0 \mathrm{~cm}$ column of Sephadex G-25 (Pharmacia Fine Chemicals, PD-10 columns), which had been equilibrated with an acetate buffer $(0.2 \mathrm{M}, \mathrm{pH} 5.0)$ containing $0.17 \mathrm{M}$ sodium chloride and $13.8 \%$ methanol. Proteins were eluted completely in $3.5 \mathrm{ml}$ of the same solvent mixture. This step removes all materials from the supernatant which absorb at $595 \mathrm{~nm}$. The amount of protein in the eluent was determined by vortexing a $50 \mu \mathrm{l}$ aliquot with $2.5 \mathrm{ml}$ of Coomassie Brilliant Blue $\mathrm{G}-250$ dye reagent (Bio Rad Protein Dye Reagent), and determining $\mathrm{A}_{595}$ after 6 minutes (Bradford 1976) using a blank consisting of $50 \mu \mathrm{l}$ of buffer plus $2.5 \mathrm{ml}$ of the dye reagent. The absorbance at $595 \mathrm{~nm}$ was transformed into $\mathrm{mg}$ of BSA by the use of a calibration curve constructed on the same day as the assay. From a determination of the amount of BSA in the original solution, the amount precipitated by the addition of the extract could be calculated. The amount of protein in the BSA-tannin precipitate cannot be measured directly, since the SDS required to redisolve the precipitate interferes with the protein assay.

\section{BSA Precipitation: Determination of Phenols Precipitated}

(Hagerman and Butler 1978). Aliquots of the stock solution derived from $1.0,1.5,2.0,2.5$ or $3.0 \mathrm{mg}$ of leaf powder diluted to $0.5 \mathrm{ml}$ were vortexed with $1.0 \mathrm{ml}$ of the same BSA solution described above. Following the rinsing proce- 
dure, the pellet was dissolved in $2 \mathrm{ml}$ of $1 \%$ SDS in $5 \%$ triethanolamine. Then $0.5 \mathrm{ml}$ of ferric chloride $(0.01 \mathrm{M}$ in $0.01 \mathrm{~N} \mathrm{HCl}$ ) was added and vigorously vortexed. $\mathrm{A}_{510}$ was measured against a distilled water blank after $15 \mathrm{~min}$.

\section{Experimental Design and Data Analysis}

Concentrations of phenolics and proanthocyanidins and measures of the protein-precipitating capacity of the foliage extracts were obtained from the regression coefficients (slopes) of linear regressions fitted to measurements performed at several different extract concentrations. This approach has several advantages over the more common practice of conducting measurements at a single concentration. The calculation of the concentration of a secondary metabolite in a foliage extract, based upon measurements conducted at a single extract concentration, assumes that a linear relationship exists between the independent variable (amount of extract used) and the dependent variable (the parameter measured in the assay), and that the y-intercept is zero. If the relationship is non-linear, or if it is linear but the intercept is not zero, then the calculated concentration will be dependent upon the amount of extract used in the assay or the amount of foliage extracted. Obviously such a dependence would preclude the use of the data in comparing extracts from different sources. By conducting measurements at several concentrations it is possible to ensure that the determinations are being performed with quantities of the extract which do generate the requisite linear relationship, and to determine how close to zero the $y$-intercept actually is. Some protein-precipitating assays, especially the $\beta$-glucosidase precipitation assay and the astringency test (Bate-Smith 1973), are characterized by large, negative y-intercepts, manifested as threshold concentrations of extract below which none of the test protein is precipitated. While it is premature to offer a definitive interpretation of these threshold effects, it would seem reasonable to suggest that they might be due to the heterogeneity of the protein preparations used in these assays. In the $\beta$-glucosidase assay it is possible that other proteins present in the enzyme preparation might form less soluble complexes with tannins than does the enzyme, thereby necessitating the addition of larger amounts of tannins to elevate the mass action product to a value in excess of the solubility product of the enzyme-tannin complex. In any event, by performing measurements at several concentrations and determining the protein-binding capacity of the extract from the slope of the linear segment of the curve beyond the threshold value, the entire problem of the negative y-intercept is avoided. The slope provides a direct measure of the protein-precipitating capacity of the constituents of the extract in a concentration range where they are actually precipitating the test protein.

Regression coefficients (slopes) and y-intercepts were calculated assuming that the independent variable (dry weight of leaf powder extracted) was measured without error, employing data in which there was more than one value of the dependent variable per value of the independent variable (Sokal and Rohlf 1969). In calculating standard errors of regression coefficients, mean squares were not pooled. The significance of differences between regression coefficents was tested at the level, $P<0.01$, using the Simultaneous Test Procedure described by Sokal and Rohlf (1969).

\section{Results and Discussion}

Assays of Oak Foliage Extracts

The Folin-Denis assay demonstrates that oak foliage typically contains comparatively high levels of phenolic constituents, and that of the six species examined, white oak and bur oak contain the highest concentrations (Table 1). Since this method assays for total phenolic content, it provides neither a direct nor an indirect measure of tannin levels, and no conclusions concerning the absolute or relative amounts of tannins in these six oak species can be drawn from the data. Nonetheless, it is a common practice to report the results of the Folin-Denis assay in terms of tannic acid equivalents ( $\mu \mathrm{g} \mathrm{TAE} / \mathrm{mg}$ ). To enable comparison of our data with other results published in this form, we have transformed the basic spectroscopic data generated in the assay, $\mathrm{A}_{725} / \mathrm{mg}$ (column 1), into $\mu \mathrm{g} \mathrm{TAE} / \mathrm{mg}$ (column 2) by the use of a calibration curve. It is important always to keep in mind that expressing the results of the FolinDenis assay as $\mathrm{TAE} / \mathrm{mg}$ does not imply that the extract contains any tannic acid or any tannins whatsoever, but only that the phenolics present generate absorbance at $725 \mathrm{~nm}$ equal to that given by the indicated quantity of tannic acid. In our opinion this style of reporting the data should be discouraged, since it can mislead the reader into concluding that tannin levels have actually been measured. In the absence of any information concerning the structures of the phenols actually present in the extract, $A_{725} / \mathrm{mg}$ would seem to be the best way to report the results of this assay.

All six species of oaks contain extractable proanthocyanidins (Table 2), commonly interpreted as an indication of the presence of condensed tannins. The basic spectrosopic data, $\triangle \mathrm{A}_{550} / \mathrm{mg}$ (column 1), have been recalculated in terms of $\mu \mathrm{g}$ bisulfited quebracho equivalents $(\mu \mathrm{g} \mathrm{BQE} /$ $\mathrm{mg}$ ) (column 2) using a suitable calibration curve. The proanthocyanidin assay is likely to underestimate total tannins, since it does not measure hydrolyzable tannins, and to overestimate condensed tannins, since it measures non-tannic

Table 1. Total extractable phenolic content (Folin-Denis assay) of the mature foliage of six oak species. The entries in the first data column are the regression coefficients (slopes) of $\mathrm{A}_{725} \mathrm{vs}$. $\mathrm{mg}$ (dry weight) leaf extracted \pm the standard error of the regression coefficient $(\mathrm{df}=2)$. Entries in the second data column are regression coefficents (slopes) of $\mu \mathrm{g}$ TAE vs. mg (dry weight) leaf extracted \pm standard error of the regression coefficient. $\mu \mathrm{g}$ TAE was calculated from $A_{725}$ using a linear regression fitted to a suitable calibration curve. Measurements were conducted at four different concentrations of two separate extracts, except in the case of white oak where five separate extracts were examined

\begin{tabular}{lll}
\hline Species & $\mathrm{A}_{725} / \mathrm{mg}^{\mathrm{a}}$ & $\mu \mathrm{g} \mathrm{TAE} / \mathrm{mg}$ \\
\hline$Q$. alba (white) & $3.02 \pm 0.03^{\mathrm{b}}$ & $156 \pm 3$ \\
Q. macrocarpa (bur) & $2.75 \pm 0.05^{\mathrm{b}, \mathrm{c}}$ & $138 \pm 2$ \\
Q. palustris (pin) & $2.44 \pm 0.03^{\mathrm{c}, \mathrm{d}}$ & $123 \pm 2$ \\
Q. bicolor (swamp white) & $2.25 \pm 0.08^{\mathrm{d}}$ & $113 \pm 4$ \\
Q. velutina (black) & $2.06 \pm 0.06^{\mathrm{d}}$ & $104 \pm 3$ \\
$Q$. rubra (red) & $2.01 \pm 0.13^{\mathrm{d}}$ & $101 \pm 6$ \\
\hline
\end{tabular}

a y-Intercepts: alba, 0.02; macrocarpa, 0.03 ; palustris, 0.05 ; bicolor, 0.02 ; veluntina, $-0.08 ;$ rubra, 0.02 . None of the $y$-intercepts are significantly different from zero $(P<0.01)$

b Values in a column followed by the same letter are not significantly different $(P<0.01)$ 
Table 2. Extractable proanthocyanidin content (HCl-butanol assay) of the mature foliage of six oak species. The entries in the first data column are the regression coefficients (slopes) of $\mathrm{AA}_{550}$ vs. $\mathrm{mg}$ (dry weight) leaf extracted \pm the standard error of the regression coefficient $(\mathrm{df}=3)$. Entries in the second data column are regression coefficients (slopes) of $\mu \mathrm{g} B Q E$ vs. mg (dry weight) leaf extracted \pm standard error of the regression coefficient. $\mu \mathrm{g} B Q E$ was calculated from $\Delta \mathrm{A}_{550}$ using a linear regression fitted to a suitable calibration curve. Measurements were conducted at five different concentrations of two separate extracts

\begin{tabular}{llc}
\hline Species & $\Delta \mathrm{A}_{550} / \mathrm{mg}^{\mathrm{a}}$ & $\mu \mathrm{g} \mathrm{BQE} / \mathrm{mg}$ \\
\hline Q. bicolor (swamp white) & $0.319 \pm 0.006^{\mathrm{b}}$ & $136 \pm 2.5$ \\
Q. macrocarpa (bur) & $0.298 \pm 0.012^{\mathrm{b}}$ & $128 \pm 5.0$ \\
$Q$. rubra (red) & $0.161 \pm 0.010^{\mathrm{c}}$ & $60 \pm 3.5$ \\
$Q$. palustris (pin) & $0.123 \pm 0.002^{\mathrm{d}}$ & $41 \pm 0.7$ \\
$Q$. velutina (black) & $0.100 \pm 0.005^{\mathrm{e}}$ & $29 \pm 1.5$ \\
Q. alba (white) & $0.061 \pm 0.001^{\mathrm{f}}$ & $10 \pm 0.3$ \\
\hline
\end{tabular}

a $\mathrm{y}$-Intercepts: bicolor, 0.097; macrocarpa, $0.128 ;$ rubra, 0.036; palustris, 0.011 ; velutina, $0.016 ;$ alba, 0.002 . Only the y-intercepts for bicolor and macrocarpa are significantly different from zero $(P<0.01)$

b Values in a column followed by the same letter are not significantly different $(P<0.01)$

monomeric flavonoids as well as condensed tannins. In any event, whatever it is that this assay measures, it is present in greatest quantities in swamp white oak and bur oak, and in lowest quantities in white oak. There is no significant correlation between the proanthocyanidin values obtained for the oak foliage extracts and Folin-Denis values $(r=$ $-0.130, \mathrm{df}=4, P<0.8)$.

We have also assayed the capacity of extracts of all six oak species to precipitate two different proteins, bovine serum albumin (BSA) and the enzyme, $\beta$-glucosidase (Table 3). In one procedure, varying amounts of foliage extract were added to an aqueous solution of BSA, and the protein-precipitating capacity of the extract was as- sessed both by determining the amount of BSA precipitated (column 1) and the amount of phenolic material precipitated (column 2). In the second procedure, foliage extract was added to a solution of a commercial preparation of $\beta$-glucosidase, and the reduction in enzymatic activity following the removal of the precipitated tannin-protein complex was measured (column 3). The results obtained from the $\beta$-glucosidase precipitation method correlate strongly with those from both modifications of the BSA precipitation procedure $(r=0.976, \mathrm{df}=4, P<0.001$, determination of BSA precipitated; $r=0.970, \mathrm{df}=4, P<0.01$, determination of phenols precipitated). Details of these assay procedures will be discussed in later publications.

The pattern of tannin levels in the six oak species which emerges from the protein-precipitation assays is strikingly different from the ones derived from the Folin-Denis and proanthocyanidin assays. The extracts exhibiting the highest protein-precipitating capacity are from pin oak and bur oak. Pin oak is a species with an intermediate Folin-Denis value and a low proanthocyanidin value. White oak, the species with the highest Folin-Denis value, has very low protein precipitating capacity. Apparently the abundant phenolic constituents of white oak foliage include only a small fraction of tannic components. Of the two species with the highest proanthocyanidin values, bur oak has a comparatively high protein-precipitating capacity while swamp white oak has only an intermediate value. From this discussion it should be evident that neither the FolinDenis assay nor the proanthocyanidin assay measures levels of extractable protein-precipitating phenolics in a foliage sample. In fact, there is no significant correlation between protein-precipitating capacity, by whatever assay it is measured, and total phenolics $(r=0.066, \mathrm{df}=4, P<0.9$, determination of BSA precipitated) or proanthocyanidins $(r=$ $0.402, \mathrm{df}=4, P<0.4$, determination of BSA precipitated). The lack of correlation between total phenols or proanthocyanidins and protein-precipitating capacity clearly precludes the uncritical use of the Folin-Denis and proantho-

Table 3. Protein-precipitating capacity of extracts of the mature foliage of six oak species. Entries in the first and second data columns are the regression coefficients (slopes) of $\mathrm{mg}$ BSA precipitated vs. $\mathrm{mg}$ (dry weight) leaf extracted and $\mathrm{A}_{510}$ (a measure of phenolics precipitated) vs. mg (dry weight) of leaf extracted \pm the standard error of the regression coefficient $(\mathrm{df}=3$ ), respectively. Measurements were conducted at five different concentrations on two separate extracts. Entries in the third data column are the regression coefficients (slopes) of units of $\beta$-glucosidase activity precipitated vs. $\mathrm{mg}$ (dry weight) leaf extracted \pm the standard error of the regression coefficient ( $\mathrm{df}=n-2$, where $n=$ number of concentrations). The number of concentrations, the number of extracts, and the total number of measurements are indicated, in that order, in the parentheses

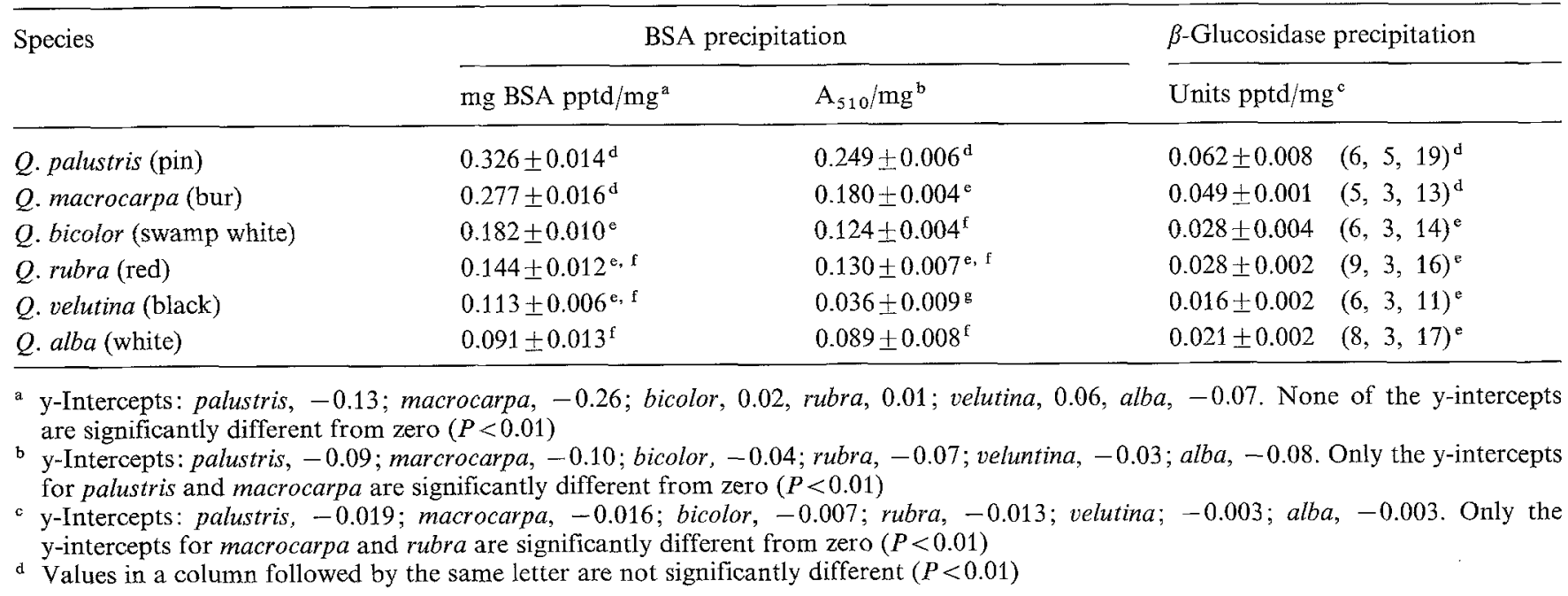


cyanidin assays in determining tannin content. Given the severe limitations in the use of these two assays, we urge their replacement by assays based upon the measurement of protein-precipitation.

The Folin-Denis and proanthocyanidin values reported in Tables 1 and 2 are as much as $25 \%$ lower than the values reported by Lawson et al. (1982), even though the assays were performed in the same laboratory on extracts prepared from the same foliage samples. The differences reflect changes which occurred during extended storage. Up to twelve months intervened between the performance of the assays reported by Lawson et al. and those described in this paper, during which time the freeze-dried, milled foliage samples were stored in a desiccator. In spite of the changes which occurred during storage, there was no alteration in the rank orders of the six species in either assay, suggesting that parallel and roughly comparable changes occurred in all of the samples. These results underscore the importance of performing assays on foliage samples as soon after collection as possible in studies designed to characterize the actual levels of secondary metabolites present in live foliage. Since the objective of this investigation was not to probe the chemical defenses of oaks, but rather to determine whether the Folin-Denis, proanthocyanidin, and protein-precipitation assays provide comparable measures of tannin levels in foliage samples, the condition of the samples is not crucial to the validity of the conclusions. The results of the three types of assays do not correlate. If they do not correlate in year-old samples, then there is no reason to believe that they will correlate in any samples, however fresh they might be.

\section{Evaluation of Protein-Precipitation Assays}

There are also limitations to the conclusions which can be drawn from protein-precipitation assays. The protein-binding properties of tannins are a function of their molecular structures. Consequently, protein-precipitating capacity is a measure not simply of the quantity of tannins present, but rather of a property of the extract which depends upon both the quantity and quality of protein-precipitating agents present. Only if the tannins in two foliage samples had similar chemical structures would a protein-precipitation assay allow a determination of relative tannin contents in the two samples. However, since in most ecologically oriented studies of the role of tannins in plant-herbivore interactions, what is important is not so much the amount of tannins present but rather the possibility that digestive efficiency might be reduced through the precipitation of plant proteins or herbivore digestive enzymes, this aspect of protein-precipitation assays would seem to be an asset rather than a liability.

Another approach to supplementing purely chemical functional group assays for foliage constituents with information of physiological importance is exemplified by the work of Waterman et al. (1980). These authors have evaluated the digestibility of a foliage sample by a rumen inoculum, and have found significant negative correlations between digestibility and both proanthocyanidin and total phenol content. This approach provides information which is invaluable in an assessment of the role of phenolics in food selection and utilization by herbivores. However, in the absence of a measure of the protein-precipitating capacity of the foliage extracts, it is not valid to attribute the reduced digestibility of the foliage to the presence of tannins. The effect could be due to non-tannic phenols with antibiotic action against rumen microorganisms.

Another important question to be considered is whether a measure of the amount of hemoglobin, $\beta$-glucosidase or BSA precipitated by a foliage extract provides a useful measure of the potential of the tannins to precipitate the actual proteins they encounter in an herbivore's gut. On an absolute basis the answer is that it is not. Proteins differ in the extent to which they are precipitated by tannins (Mandels and Reese 1963; van Sumere et al. 1975). A tannic extract which will precipitate $1 \mathrm{mg}$ of BSA will not necessarily precipitate $1 \mathrm{mg}$ of leaf protein or $1 \mathrm{mg}$ of insect digestive enzyme. However, relative protein-precipitating capacities of tannins derived from different sources appear to be the same when measured against different test proteins, as indicated by the highly significant correlation $(r=$ 0.976, $\mathrm{df}=4, p<0.001$ ) between the protein-precipitating capacity of oak foliage extracts when measured against BSA and when measured against $\beta$-glucosidase. It would seem reasonable to suppose, therefore, that the same rank order of protein-precipitating capacity among the six oak species would be observed with other proteins. Studies using leaf proteins, such as ribulose-1,5-diphosphate carboxylase, would be useful, not only to provide a further test of this supposition, but also to test directly the degree to which tannins might precipitate proteins actually present in the diets of herbivores.

At the present time investigators have three proteinbinding assays to choose from: (1) hemoglobin-precipitation (the astringency assay), (2) $\beta$-glucosidase-precipitation, and (3) BSA-precipitation.

In the astringency assay, which has been used with great effectiveness in chemotaxonomic studies by Bate-Smith $(1973,1977,1981)$, the amount of hemoglobin precipitated from a solution of freshly lysed blood following the addition of the tannin-containing extract is determined by noting the reduction of absorption at $578 \mathrm{~nm}$. Unfortunately, tannin levels must exceed a rather high threshold value before any hemoglobin precipitates, possibly because other blood proteins precipitate first. In addition, many plant extracts absorb at $578 \mathrm{~nm}$. These two complications reduce the sensitivity of the assay and make the results strongly dependent upon the ratio employed of extract to blood, especially for extracts low in tannins. Recent studies of Schultz et al. (1981) have enhanced the value of this method in assaying for tannins.

The $\beta$-glucosidase precipitation method, developed by Becker and Martin (1982) from procedures described by Goldstein and Swain (1965), circumvents some, but not all, of the problems of the astringency test. This assay is also characterized by a threshold value of extract concentration, albeit a lower one than in the case of the hemoglobin precipitation assay, below which no enzyme is precipitated. Absorbing compounds in the plant extract do not interfere. Unfortunately, this assay is time-consuming, and the procedure is somewhat cumbersome. Details of the method discussed elsewhere (Becker and Martin 1982).

The BSA-precipitation method was developed by Hagerman and Butler (1978) to compare tannin levels in different strains of sorghum. In their procedure, tannin content is determined by adding the extract to a solution of BSA, isolating the insoluble BSA-tannin precipitate, redissolving it in an alkaline-SDS solution, and measuring the amount 
of redissolved phenolics using ferric chloride. Since the tannin measurement depends upon a phenol measurement, the value obtained depends not only upon the amount of tannin precipitated and subsequently redissolved, but upon its structure as well. While this approach may be admirably suited to comparisons of tannin levels in different strains or populations of the same species, which differ only in the amount and not in the structures of the tannins present, it is not an appropriate method for comparing different species which have tannins with very different structures and different numbers of phenolic hydroxyl groups. We have modified the Hagerman and Butler procedure so that it measures the amount of protein precipitated from a solution by an extract rather than the amount of phenol precipitated from an extract by a protein. Using Bradford's protein-dye binding procedure (Bradford 1976), we determined the BSA concentration in the original solution and the amount remaining in the supernatant after the addition of the tannin-containing extract and removal of the BSA-tannin precipitate by centrifugation. Although the original method of Hagerman and Butler (Table 3, column 2) and our modification (Table 3, column 1) correlate fairly well $(r=0.924, \mathrm{df}=4, P<0.01)$ when applied to the six oak species, some discrepancies are evident. For example, the positions of swamp white oak and red oak in the rank orders are interchanged. We suspect that this discrepancy reflects different structures and possibly different protein-binding properties of the tannins present in these two species.

\section{Conclusion}

Defining the status of tannins as defensive chemicals in plants is crucial to the development of a general theory of plant-herbivore interactions. It would be helpful if investigators in this area would use assay procedures for tannins which are based upon those properties presumed to be functionally important in making tannins effective defensive chemicals. Since the physiological activities of tannins are attributed largely to their capacity to bind and precipitate proteins, protein-precipitation assays would seem to be the assays of choice in such studies. We have described a convenient and reliable procedure for measuring the amount of BSA precipitated by the extractable constituents of a sample of plant tissue. We urge the routine adoption of this or a comparable assay by investigators concerned with chemical aspects of plant-herbivore interactions.

Acknowledgements. This research was supported in part by a grant from the National Science Foundation to M.M. Martin (PCM7822733). We thank Dan Lawson (Department of Entomology, Michigan State University) for supplying the foliage samples used in this study. We thank Peter Becker and Dan Lawson for their criticisms of an earlier version of this manuscript.

\section{References}

Bate-Smith EC (1973) Haemanalysis of tannins: the concept of relative astringency. Phytochemistry 12:907-912

Bate-Smith EC (1977) Astringent tannins of Acer species. Phytochemistry 16:1421-1426

Bate-Smith EC (1981) Astringent tannins of the leaves of Geranium species. Phytochemistry 20:211-216

Becker P, Martin JS (1982) Protein-binding capacity of tannins in Shorea (Dipterocarpaceae) seedling leaves. J Chem Ecol. in press

Bernays EA, Chamberlain D, McCarthy P (1980) The differential effects of ingested tannic acid on different species of Acridoidea. Entomol Exp Appl 28:158-166

Bernays EA, Chamberlain DJ, Leather EM (1981) Tolerance of acridids to ingested condensed tannin. J Chem Ecol 7:247-256

Bradford M (1976) A rapid and sensitive method for the quantitation of microgram quantities of protein utilizing the principle of protein-dye binding. Anal Biochem 72:248-254

Burns RE (1971) Method for estimation of tannin in sorghum grain. Agron J 63:511-512

Chan BG, Waiss AC, Lukefahr M (1978) Condensed tannin, an antibiotic chemical from Gossypium hirsutum. J Insect Physiol 24:113-118

Feeny PP (1968) Effect of oak leaf tannins on larval growth of the winter moth Operophthera brumata. J Insect Physiol 14:805-817

Feeny PP (1970) Seasonal changes in oak leaf tannins and nutrients as a cause of spring feeding by winter moth caterpillars. Ecology $51: 565-581$

Feeny P (1976) Plant apparency and chemical defense. Rec Adv Phytochem 10:1-40

Fox LR, Macauley BJ (1977) Insect grazing on Eucalyptus in response to variation in leaf tannins and nitrogen. Oecologia (Berl) 29:145-162

Goldstein JL, Swain T (1965) The inhibition of enzymes by tannins. Phytochemistry 4:185-192

Govindarajan VS, Mathew AG (1965) Anthocyanidins from leucoanthocyanidins. Phytochemistry 4:985-988

Hagerman AE, Butler LG (1978) Protein precipitation method for the quantitative determination of tannins. J Agric Food Chem $26: 809-812$

Haslam E (1979) Vegetable tannins. Rec Adv Phytochemistry $12: 475-523$

Hillis WE, Swain T (1959) The phenolic constituents of Prunus domesticus. II-The analysis of tissues of the Victoria plum tree. J Sci Food Agric 10:135-144

Lawson DL, Merritt RW, Klug MJ, Martin JS (1982) The utilization of late season foliage by the orange striped oakworm, $\mathrm{An}$ isota senatoria (J.E. Smith) (Citheroniidae). Entomol Exp Appl, in press

Mandels M, Reese ET (1963) Inhibition of cellulases and $\beta$-glucosidases. In: ET Reese (ed), Advances in enzymic hydrolysis of cellulose and related materials. Pergamon Press, New York, pp 115-157

McKey D, Waterman PG, Mbi CN, Gartlan JS, Struhsaker TT (1978) Phenolic content of vegetation in two African rain forests: ecological implications. Science 202:61-64

Moran N, Hamilton WD (1980) Low nutritive quality as a defense against herbivores. J Theor Biol 86:247-254

Oates JF, Waterman PG, Choo GM (1980) Food selection by the South Indian leafmonkey, Presbytis johnii, in relation to leaf chemistry. Oecologia (Berl) 45:45-56

Price ML, Van Scoyoc S, Butler LG (1978) A critical evaluation of the vanillin reaction as an assay for tannin in sorghum grain. J Agric Food Chem 26:1214-1218

Rhoades DF (1979) The antiherbivore chemistry of Larrea. In TJ Mabry, JH Hunziker and DR DiFeo (eds). Creosote bush: biology and chemistry of Larrea in New World deserts. Dowden, Hutchinson and Ross, Stroudsbourg, $\mathrm{Pa}$, pp 135-175

Rhoades DF, Cates RG (1976) A general theory of plant antiherbivore chemistry. Rec Adv Phytochem 10:168-213

Ribéreau-Gayon P (1972) Plant phenolics, Oliver and Boyd, Edinburgh, $x i+201 \mathrm{pp}$

Schultz JC, Baldwin IT, Nothnagle PJ (1981) Hemoglobin as a binding substrate in the quantitative analysis of plant tannins. J Agric Food Chem 29:823-826

Sokal RR, Rohlf FJ (1969) Biometry. W.H. Freeman and Co, San Francisco, pp $428-440$

Sumere CF van, Albrecht J, Dedonder A, de Pooter H, Pé I (1975) 
Plant protein and phenolics. In: JB Harborne and CF Van Sumere (eds), The chemistry and biochemistry of plant proteins. Academic Press, New York, pp 211-264

Swain T, Hillis WE (1959) The phenolic constituents of Prunus domestica. I. The quantitative analysis of phenolic constituents. J Sci Food Agric 10:63-68

Swain T (1979a) Tannins and lignins. In GA Rosenthal and DH Janzen (eds) Herbivores: their interaction with secondary plant metabolites. Academic Press, New York, pp 657-682
Swain T (1979b) Phenolics in the environment. Rec Adv Phytochemistry 12:617-640

Waterman PG, Mbi CN, KcKey DB, Gartlan JS (1980) African rainforest vegetation and rumen microbes: phenolic compounds and nutrients as correlates of digestibility. Oecologia (Berl) 47:22-33

Received December 24, 1981 